О. Б. Яременко, Д. Л. Федьков, Д. В. Добрянський, П. Ф. Дудка, Р. І. Ільницький, І. П. Тарченко, А. В. Меліксетян Національний медичний університет імені О. О. Богомольця, м. Київ

\title{
ЗМІНА ФОРМАТУ ПРОВЕДЕННЯ ЛЕКЦІЙНИХ ЗАНЯТЬ ДЛЯ СТУДЕНТІВ-МЕДИКІВ НОВОГО ПОКОЛІННЯ
}

\author{
O. B. Iaremenko, D. L. Fedkov, D. V. Dobrianskyi, P. F. Dudka, \\ R. I. Ilnytskyi, I. P. Tarchenko, A.V. Meliksetyan \\ O. Bohomolets National Medical University, Kyiv

\section{CHANGING THE FORMAT OF LECTURE CLASSES FOR NEW GENERATION MEDICAL STUDENTS}

\begin{abstract}
Мета роботи - продемонструвати потреби студентів щодо оновлення формату проведення лекційних занять і можливі шляхи її реалізації.

Основна частина. Вимогою сьогодення є підготовка нових лікарів як компетентних, мобільних, здатних вдосконалюватися та швидко орієнтуватися у сучасному світі науки і медицини. Зміна поколінь привела до зниження ефективності застарілих навчальних підходів. Це диктує потребу в оновленні навчальних програм і впровадженні інтерактивних, більш гнучких підходів до навчання. Нами було проведено анонімне анкетування 2139 студентів 3-6 курсів медичних факультетів Національного медичного університету імені О. О. Богомольця, яке дало можливість оцінити ставлення сучасних студентів до лекцій.

Загалом студенти досить високо оцінюють користь від лекційних занять, більшість опитаних вважає, що отримує з лекцій близько 60 \% навчального матеріалу. Більшість студентів, які взяли участь в анкетуванні, висловила позицію, що усні лекції клінічних дисциплін потрібні, але потребують істотної зміни формату. Існуючий формат лекцій задовольняє лише 14 \% опитаних студентів. Основними недоліками існуючого формату лекцій студенти вважають повторення інформації 3 підручників/ посібників і брак конкретних клінічних прикладів.

Висновки. Оптимальним форматом лекцій для клінічних кафедр студенти вважають такий: загальна тривалість лекції має бути 45 хв і включати 2 блоки по 20 хв із 5-хвилинною перервою між ними. В одному блоці повинна міститися сучасна інформація щодо клінічної симптоматики, діагностики і лікування захворювань, в другому - розбір клінічних випадків 3 прикладами формулювання діагнозів, планом обстеження і лікування.
\end{abstract}

Ключові слова: анкетування; методи викладання; студенти; лекції; технології навчання.

The aim of the work - to learn the use of students' needs for updating the format of conducting lecture classes and possible ways of their implementation.

The main body. Challenges of modern time require training of new doctors as competent, mobile, and able to perfection and quick orientation in the scientific world and medicine. Change in generations of university teachers has led to failure of effectiveness of outmoded teaching approaches. It's needed the renovation of university curricula and the implementation of interactive, more flexible approaches to learning and teaching. We conducted an anonymous questionnaire of 2139 students of 3-6 courses of medical faculties of O. Bohomolets National Medical University, that we were gave an opportunity to assess the attitude of our students to lectures.

In general, students highly appreciate the benefits of the lectures; most respondents believe that they receive and assimilate about $60 \%$ of the educational materials from these lectures. Most of the students who took part in the survey expressed answer that oral lectures on clinical disciplines are needed, but are required significant changes in the format. The existing format of our lectures is satisfied by only $14 \%$ of the interviewed students. They consider that common disadvantages of the existing format of lectures are the repetitions of information from textbooks or/and manuals and the lack of specific clinical typical cases.

Conclusions. Students consider the optimal format of lectures for clinical departments as follows: the total duration of the lecture should be 45 minutes and include 2 blocks for 20 minutes with a 5 minute break between them. Firstblock should contain up-to-date information about clinical features, diagnostics and treatment of diseases, the second block - the analysis of clinical cases with examples of the formulation of diagnosis, the plan of additional examinations and methods of treatment.

Key words: questionnaires; teaching methods; students; new format of the lectures; educational technology.

Вступ. Аналізуючи сучасні тенденції в освіті, а також світовий досвід викладання медицини, керівництво Національного медичного університету

() О. Б. Яременко, Д. Л. Федьков, Д. В. Добрянський та ін.
(НМУ) імені О. О. Богомольця зробило висновок про необхідність впровадження істотних змін у навчальний процес. Така необхідність пов'язана, перш за все, зі зміною поколінь студентів. Сьогод- 
нішні студенти народились у вік інформаційних технологій, навчилися користуватися комп’ютером і різними гаджетами раніше, ніж читати. Вони вміють швидко знаходити потрібну їм інформацію і потребують нових освітніх технологій [6].

Як зазначила ректор НМУ імені О. О. Богомольця Катерина Амосова, “у викладацькому середовищі дуже люблять говорити про переваги “старої школи”. Але вони не враховують однієї простої істини - модель, за якою навчали успішних представників нашого покоління, на теперішніх студентах “працює” погано внаслідок суттєвих відмінностей між поколіннями” [3].

Покоління Y, або міленіали, - це покоління народжених у період початку 80-х по кінець 90-х років минулого століття. Покоління “ігрек” сформувалося в той час, коли мережа “Інтернет” викликала глобальний переворот у традиційних засобах масової інформації. Знання вони знаходять переважно не у книжках з бібліотек, а на інтернет-ресурсах. Це покоління вільнодумців. Вкрай важливим для цього покоління є можливість самовираження [4, 5].

Покоління Z (центеніали) - це покоління народжених вже у XXI столітті. Центеніали можуть миттєво отримати сучасну інформацію з будь-якої частини світу, і для них вчитель перестав бути основним джерелом знань. Для цього покоління він радше мудрий провідник і наставник. Центеніалам важко зосередитися: щоб вивчити певний матеріал, їм варто часто змінювати види діяльності. Серед представників покоління Z багато гіперактивних студентів і лідерів. Основна проблема покоління $\mathrm{Z}$, яке “виросло в Інтернеті”, полягає в тому, що ці студенти не пристосовані до офлайн-методик навчання 3 минулого і не вважають за потрібне запам’ ятовувати інформацію. Це особливість споживання контенту новим поколінням Z, і викладачам потрібно прийняти те, як вони сприймають інформацію. Ось що необхідно розуміти, якщо стоїть завдання навчити представників покоління Z: вони не хочуть і вже не можуть вчитися “по-старому”. Вони прагнуть інтерактиву, конкретно поставлених навчальних цілей і професійної практичної спрямованості [5].

Також необхідно звернути увагу на те, що саме суспільство потребує вже іншої медицини. Так, в Україні з 1 січня 2018 р. стартувала медична реформа, в якій передбачено запровадження електронної системи медичних даних eHealth і доступ до мережі “Інтернет” навіть у віддалених селах. Лікарі змо- жуть користуватися інформацією з мережі, а також дистанційно консультуватися з колегами. Розвиток інфраструктури та додаткове фінансування сфери охорони здоров'я в селах парламент запровадив Законом “Про підвищення доступності та якості медичного обслуговування в сільській місцевості” $[1,2]$. Але оновлення медичного обладнання i технічних засобів не зможуть забезпечити підвищення якості надання медичної допомоги без змін у медичній освіті. Пацієнта лікує лікар, і саме від рівня його освіти перш за все залежатиме життя та здоров'я хворого. Впровадження нових методів і навчальних технологій у медичній освіті сприятимуть підвищенню її якості і, як наслідок, покращенню медичного обслуговування населення.

Все це диктує потребу в оновленні навчальних програм і впровадженні інтерактивних, більш гнучких підходів до навчання. Враховуючи це, Цикловій методичній комісії з терапевтичних дисциплін НМУ імені О. О. Богомольця було доручено провести анонімне опитування студентів 3-6 курсів медичних факультетів відносно можливих шляхів підвищення якості проведення лекційних занять 3 клінічних дисциплін.

Мета роботи - продемонструвати потреби студентів щодо оновлення формату проведення лекційних занять і можливі шляхи її реалізації.

Основна частина. 3 використанням інтернеттехнологій було проведено опитування студентів НМУ імені О. О. Богомольця. В опитуванні взяли участь 2139 студентів 3-6 курсів медичних факультетів університету. В анкеті студентам було запропоновано визначити ставлення до існуючого формату лекцій, сформулювати, яку частину навчального матеріалу студенти отримують під час лекції, що студентів не влаштовує в існуючому форматі усних лекцій, їх потенційну зацікавленість у різних варіантах формату лекцій, а також ставлення до використання навчальних, доступних on-line, відеоматеріалів.

Результати опитування показали, що більшість студентів-респондентів (36,5 \%) відмітила, що 60 \% навчального матеріалу вони отримують під час усних лекцій. 30,3 \% респондентів вважають, що під час лекцій вони набувають інформацію щодо певної теми лекції лише в обсязі 40 \%. 20,9 \% опитаних дотримуються думки, що лекції дають лише 20 \% інформації, хоча були й такі студенти (1,3%), які під час усної лекції отримують знання в повному обсязі (100%), 11 \% студентів зазначили, що під час лекції вони засвоюють 80 \% інформації. 
Існуючий формат лекцій задовольняє лише $14 \%$ респондентів, 68,4 \% бажають зміни даного формату, 17,2 \% взагалі не бажають їх слухати.

На підставі вивчення досвіду провідних зарубіжних медичних університетів і результатів опитування лекторів кафедр терапевтичного профілю студентам було запропоновано для вибору різні формати лекцій.

Формат 1 - тривалість 45 хв, 2 блоки по 20 хв: 15 хв сучасної інформації щодо діагностики і лікування + 5 хв обговорення; перерва -5 хв; 15 хв клінічний випадок із формулюванням діагнозу, плану обстеження і листка призначень +5 хв обговорення.

Формат 2 - скорочення тривалості лекції до 45 хв зі збереженням існуючої структури лекції та зі збільшенням актуальності, інформативності, клінічної спрямованості матеріалу.

Формат 3 - тривалість 60 хв, 2 блоки по 25 хв із перервою 10 хв, перевага віддається обговоренню проблемних питань, що передбачає Вашу підготовку до лекції, у тому числі з використанням доступних в Інтернеті відеопрезентацій/відеолекцій, зі збільшенням кількості наочних матеріалів, конкретних клінічних прикладів.

Формат 4 - традиційні усні лекції, які існують сьогодні (тривалість 90 хв із перервою).

Потенційну зацікавленість у різних форматах лекцій оцінювали за 10-бальною шкалою. Більшість студентів-респондентів підтримала формат 1 з оцінкою 7,37 бала. Скорочення тривалості лекції до 45 хв зі збереженою існуючою структурою, але за умов збільшення уваги актуальності, клінічної спрямованості матеріалу (формат 2), студенти оцінили в 5,71 бала. Подібним чином дали оцінку формату 3 (5,58 бала). Студенти вважають, що лекція повинна тривати 60 хв, здвома блоками по 25 хв і перервою 10 хв. На лекції повинні бути наочні матеріали, обов'язкова демонстрація клінічних випадків. Така лекція передбачає підготовку студента до лекції, обговорення важливих проблемних питань. Традиційний формат лекції студенти-респонденти оцінили лише в 4,1 бала.

На запитання “Що Вас не влаштовує в існуючому форматі усних лекцій?” респонденти надали кілька варіантів відповідей. Більшість студентів - 1542 (72,1 \%) відмітили, що на лекції повторюється інформація з підручників або навчальних посібників, 1044 студенти (48,8 \%) акцентували свою увагу на недостатності конкретних клінічних прикладів, 819 студентів (38,8 \%) вважають лекції неінформативними, 611 студентів (28,6 \%) - занадто довгими. Цікавий факт: 514 студентів (24 \%) бажають мати зворотний зв'язок із лектором, а 313 респондентів відмітили, що усні лекції $є$ занадто складними, i вони їх взагалі не сприймають.

Дані анонімного анкетування засвідчили, що студенти все частіше користуються відеопрезентаціями або відеолекціями, доступними в інтернеті, особливо за умов широкого вибору тем. 33,6 \% опитаних стверджують, що знайомляться з наявними в інтернет-просторі відеоматеріалами один раз на місяць, 26,5 \% - раз на тиждень, 24,5 \% - частіше, ніж раз на тиждень, тільки 15,1 \% респондентів взагалі ними не цікавляться.

Студенти $€$ активними користувачами доступних в Інтернеті відеопрезентацій/відеолекцій. За умови наявності в інтернеті широкого вибору тем відеопрезентацій/відеолекцій потенційну зацікавленість в них виявляють майже всі студенти (96,2 \%), 63,2 \% планують користуватися ними кілька разів на тиждень, але зустрічаються і такі, що не користуються цим матеріалом ніколи.

Отримавши результати аналізу анкетування студентів та оцінивши стан засвоєння лекційних матеріалів, керівництво НМУ імені О. О. Богомольця, грунтуючись на положеннях Закону України “Про вищу освіту” (від 01.07.2014 р. № 1556-VII зі змінами), розробило нові принципи проведення лекційних занять. Відтепер це не традиційне читання лекцій, а проведення повноцінного інтерактивного лекційного заняття, у якому студент $€$ активним учасником. Новий формат проведення лекцій запроваджено наказом НМУ імені О. О. Богомольця “Про заходи з удосконалення підготовки та проведення лекцій в Університеті”, де сформулювало основні вимоги до проведення лекції. Серед нових вимог: тривалість лекції - 45 (не більше 60) хв, формулювання кореневої концепції лекції, викладення практично спрямованих навчальних цілей, мотивуючий початок, обов'язкова наявність клінічних кейсів, інтерактивна взаємодія зі слухачами, формулювання ключових висновків (take homemessages), відповіді на запитання. Також наказом було регламентовано в якості обов'язкового компонента кожної лекції проведення анонімного опитування студентів, яке забезпечує "зворотний зв'язок” і обов'язково аналізується лектором та завідувачем кафедри, обговорюється на методичній нараді кафедри, включається до річного звіту про роботу кафедри; самі анкети зберігаються на кафедрі впродовж 2 років.

Висновки. Більшість опитаних студентів (68,4 \%) вважає, що усні лекції з клінічних дисциплін по- 
трібні, але зі зміною формату. Оптимальним форматом лекцій для клінічних кафедр студенти вважають такий: загальна тривалість лекції має бути 45 хв і включати 2 блоки по 20 хв - 15 хв сучасної інформації щодо діагностики і лікування захворювань +5 хв обговорення; 5 хв перерва; 15 хв розбір клінічних випадків з прикладами формулювання діагнозів, планом обстеження і лікування + 5 хв об-

\section{Список літератури}

1. Про державні фінансові гарантії медичного обслуговування населення : Закон України від 10.04.2017 р. № 6327.

2. Про підвищення доступності та якості медичного обслуговування в сільській місцевості : Закон України від 14.11.2017 р. № 7117. - URL : https://ukr.lb.ua/ news/2017/10/19/379645_rada_priynyala_pershomu_ chitanni.html.

3. Амосова К. Хто такі “міленіали”, і як навчати таких студентів / К. Амосова. - URL : http://nmu.ua/ ru/news/ kateryna-amosova -hto-taki-milenialy-yak-navchaty-takyhstudentiv.

\section{References}

1. Zakon Ukrainy Pro derzhavni finansovi harantii medychnoho obsluhovuvannia naselennia vid 10.04.2017 r. № 6327 [The Law of Ukraine On State Financial Guarantees of Medical Care of the Population No. 6327 dated April 10, 2017]. [in Ukrainian].

2. Zakon Ukrainy Pro pidvyshchennia dostupnosti ta yakosti medychnoho obsluhovuvannia v silskii mistsevosti vid 14.11.2017 r. № 7117 [Law of Ukraine On improving the availability and quality of health care in rural areas dated November 14, 2017 No. 7117]. Retrieved from: https://ukr. lb.ua/news/2017/10/19/379645_rada_priynyala_pershomu_ chitanni.html [in Ukrainian].

3. Amosova, K. Khto taki “Milenialy”, i yak navchaty takykh studentiv [Who are the "Millennials", and how to teach such students]. Retrieved from: http://nmu.ua/ ru/ говорення. Основними недоліками існуючого формату лекцій студенти вважають повторення інформації з підручників/посібників і брак конкретних клінічних прикладів. Ефективність запровадженого в НМУ імені О. О. Богомольця нового формату лекцій потребує подальшого проспективного аналізу.

4. Амосова К. “Лікар із смартфоном”: Національний медичний університет модернізує освітній процес / K. Амосова. - URL : http://nmu.ua/news/likariz-smartfonom-natsionalnyj-medychnyj-universytetmodernizuye-osvitnij-protses.

5. Слаква Ю. Теорія поколінь (х, у, z) / Ю. Слаква. URL : https://www.learning.ua/blog/201711/teoriia-pokolin$\mathrm{x}-\mathrm{y}-\mathrm{z}$.

6. Фіцула М. М. Педагогіка вищої школи / М. М. Фіцула. - 2-ге вид., доповн. - Академ. видав., 2014. - 456 с.

news/ kateryna-amosova -hto-taki-milenialy-yak-navchatytakyh-studentiv.

4. Amosova, K. "Likar iz smartfonom": Natsionalnyi medychnyi universytet modernizuie osvitnii protses [“Doctor with a smartphone”: National Medical University modernizes the educational process]. Retrieved from: http:// nmu.ua/news/likar-iz-smartfonom-natsionalnyj-medychnyjuniversytet-modernizuye-osvitnij-protses [in Ukrainian].

5. Slakva, Yu. (2014). Teoriia pokolin $(x, y, z)$ [Theory of generations $(x, y, z)]$. Retrieved from: https://www.learning. ua/blog/201711/teoriia-pokolin-x-y-z [in Ukrainian].

6. Fitsula, M.M. (2014). Pedahohika vyshchoi shkoly 2-he vyd. dopovn. [Pedagogics of the higher school ( $\left.\left.2^{\text {nd }} e d . r e v.\right)\right]$. Akadem. vydav [in Ukrainian]. 